\title{
A Magyar Genomikai Egészségtárház az egészséges hosszú élet kutatásának szolgálatában
}

\author{
Várhegyi Vera dr. ${ }^{1}$ - Molnár Viktor dr. ${ }^{1}$ - Gézsi András ${ }^{1,2}$ - Sárközy Péter ${ }^{2}$ \\ Antal Péter dr. ${ }^{2}$ - Molnár Mária Judit dr. ${ }^{1}$ \\ ${ }^{1}$ Semmelweis Egyetem, Általános Orvostudományi Kar, Genomikai Medicina és Ritka Betegségek Intézete, \\ Budapest \\ ${ }^{2}$ Budapesti Múszaki Egyetem, Méréstechnika és Információs Rendszerek Tanszék, Budapest
}

\begin{abstract}
A fejlett társadalmak egészségügyi rendszereinek legnagyobb kihívását az öregedéssel összefüggő, korfüggő betegségek jelentik. Annak megértéséhez, hogy az egyes genetikai variánsoknak mi a szerepük egy korfüggő betegség kialakulásában, meg kell ismerkednünk magával az öregedési folyamattal, az egészséges hosszú élettel asszociált, valamint az adott populációra jellegzetes variánsokkal is. A Semmelweis Egyetem Genomikai Medicina és Ritka Betegségek Intézete a Nemzeti Bionika Program keretén belül a Magyar Genomikai Egészségtárház felállítását túzte ki célul, időskoruk mellett is egészséges önkéntesek teljesgenom-szekvenciáinak és kapcsolódó fenotípusadatainak katalogizálásával és elemzésével, létrehozva az első magyar teljes genomi referencia-adatbázist. Fontos szempont volt, hogy a kutatás az egészséges öregedést vizsgáló nemzetközi projektekhez is kapcsolódást biztosítson, így lehetőséget teremtve a különböző országokból származó adatok harmonizálására és közös elemzésére. A kutatás résztvevőinek 49\%-a 70-80 éves, 36\%-a 81-90 éves, 14\%-uk pedig 90 év feletti; a nemek aránya 44/56\%-os megoszlást mutatott a férfiak és a nók között. A résztvevők csaknem fele (46\%) egyedül él. Magas a felsőfokú végzettségúek aránya (46\%), a résztvevők 61\%-a hosszú időn át sportolt, 70\%-uk sosem dohányzott. A vizsgálati alanyok szülei is magas életkort éltek meg, az édesapáknál 74,3, az édesanyák esetében pedig 80,47 év volt a halálozáskori átlagéletkor. Adattárházunk elsóként tervez hozzáférést biztosítani egy magyar teljes genomi referencia-adatbázishoz, amely a genetikusan meghatározott betegségek és fenotípusok kutatásában és a klinikai gyakorlatban is alapvető fontosságú. A projekt bioinformatikai fejlesztései a genetikai/genomikai információk többszintű elérését támogatják a személyes adatok védettségét megőrző statisztikai elemzési és mesterségesintelligencia-eljárások segítségével.
\end{abstract}

Orv Hetil. 2021; 162(27): 1079-1088.

Kulcsszavak: egészséges öregedés, teljes genom, prediktív genetikai markerek, Magyar Genomikai Egészségtárház, adatvédelmet biztosító adatelemzés

\section{Hungarian Genomic Data Warehouse supporting the healthy ageing research}

Genetics has proven to be a a successful approach in the study of ageing. To understand the role of each genetic variant in the development of an age-dependent disease, we need to become familiar with the ageing process itself and with the population-specific variants. The Institute of Genomic Medicine and Rare Disorders of the Semmelweis University within the framework of the National Bionics Program set up a data collection, the Hungarian Genomic Data Warehouse, by cataloging and analyzing complete genome sequences and related phenotype data of healthy volunteers, which also serves as a reference national Hungarian genomic database. The structure of the data warehouse allows interoperability with the most important international research projects on ageing. $49 \%$ of the participants in the Hungarian Genomic Data Warehouse were 70-80 years old, 36\% were 81-90, 14\% over 90 years old. The gender ratio was $44 / 56 \%$ between men and women. The proportion of people with higher education is high $(46 \%), 61 \%$ of the participants played sports for a long time, and $70 \%$ never smoked. The parents of the participants also lived a high age, with an average age at death of 74.3 years for fathers and 80.47 years for mothers. The Hungarian Genomic Data Warehouse can provide vital and timely support in personalized medicine, especially in the research and diagnosis of genetically inherited disorders. The long-term goal of these bioinformatic developments is to provide access at multiple levels to the genomic data using privacy-preserving data analysis methods in genomics. 
Keywords: healthy ageing, whole genome, predictive genetic markers, genomic data warehouse, privacy-preserving data analysis

Várhegyi V, Molnár V, Gézsi A, Sárközy P, Antal P, Molnár MJ. [Hungarian Genomic Data Warehouse supporting the healthy ageing research.] Orv Hetil. 2021; 162(27): 1079-1088.

(Beérkezett: 2020. december 7.; elfogadva: 2021. január 18.)

\section{Rövidítések}

BANF1 = BAF [barrier to autointegration factor] nuclear assembly factor 1 ; BBMRI $=($ Biobanking and BioMolecular Resources Research Infrastructure) Biobank és Biomolekuláris Infrastrukturális Kutatóintézet; CI $=$ (confidence interval) konfidenciaintervallum; $\mathrm{CpG}=$ (cytosine-phosphate-guanine) citozin-foszfát-guanin; DNS = dezoxiribonukleinsav; $\mathrm{EKG}=$ elektrokardiográfia; HIV = (human immunodeficiency virus) emberi immunhiányt előidézô vírus; $\mathrm{IgG}=$ immunglobulin-G; $\mathrm{LDL}=($ low-density lipoprotein $)$ alacsony sürúségú lipoprotein; LMNA = lamin A és lamin C fehérjéket kódoló gén; MoCA $=($ Montreal Cognitive Assessment $)$ Montreali Kognitív Felmérés; OMIM = (Online Mendelian Inheritance in Man $) \mathrm{a}$ 'Mendeli öröklődés emberben' projekt online adatbázisa; OTKA = Országos Tudományos Kutatási Alapprogramok; POLR3A $=($ RNA polymerase III subunit $\mathrm{A})$ ribonukleinsavpolimeráz III, A alegység; USP = (ubiquitin carboxyl-terminal hydrolase) ubikvitin karboxiterminális hidroláz; WHO = (World Health Organization) Egészségügyi Világszervezet; WRN = a Werner-szindrómában érintett gén

\section{Az öregedő társadalomra nehezedő betegségteher}

Az Egészségügyi Világszervezet (WHO) 2020 májusában tagállamainak jóváhagyásával indította útnak a „Decade of Healthy Ageing (2020-2030)" (Az Egészséges Idősödés Évtizede [2020-2030]) globális stratégiáját, amely összehangolt fellépésre hívja a kormányokat, nemzetközi ügynökségeket, szakembereket, tudományos köröket, a médiát, a magánszektort és a civil társadalmat a mára egymilliárd föt is meghaladó létszámú 60 év felettiek, családjuk és azon közösségek életének javítása érdekében, amelyben élnek [1].

$\mathrm{Az}$ öregedéssel összefüggő betegségek a fejlett ipari társadalmak egészségügyi rendszereinek egyik legfontosabb problémáját jelentik. A fejlett országok összhalálozásának mintegy 90\%-át teszik ki az öregedéssel kapcsolatos halálokok. Mivel az öregedéssel összefüggó kórképek az egészségügyi kiadások jelentős százalékáért felelősek, az egészségben eltöltött hosszú élet hátterének kutatása gazdasági szempontból is jelentőséggel bír.

Az egészen a 20. század első feléig jelen lévő, magas fertilitással és magas mortalitással jellemzett emberi népesedési dinamikát napjainkra a világ fejlett államai után már a fejlődő országokban is a csökkenő fertilitási és mortalitási mutatók felé való eltolódás váltja fel [2].
A WHO-nak az életkor és az egészségi állapot összefüggéseivel foglalkozó elemzése szerint az elmúlt évtizedek trendje alapján 2050-re a 65 éven felüliek népességbeli aránya 188\%-kal, a 85 éven felülieké mintegy 351\%-kal emelkedhet [2]. A jelenlegi tendenciák alapján az országok többségében a 60 évnél idősebbek aránya a 2017ben mért 1 : 8-ról 2030-ra 1 : 6-ra, majd 2050-re 1 : 5-re emelkedik. Noha a népesség várható élettartama az elmúlt évtizedekben folyamatosan nőtt, ez inkább a jobb orvosi ellátásnak és a szociális körülmények javulásának tulajdonítható, mint a jobb egészségnek.

$\mathrm{Az}$ összes korcsoportban javuló egészségi állapot és növekedő várható élettartam a civilizáció tagadhatatlan vívmánya. Az egészségben eltöltött, betegségmentes élettartam (egészségtartam) azonban nem növekedett annyira, mint az élettartam. 2000 és 2015 között a várható élettartam globálisan öt évvel történő növekedését az egészséges élettartam mindössze 4,6 éves emelkedése kísérte. A késői indulású megbetegedések az élet átlagosan 16-20\%-át teszik ki, amely a nők, az alacsonyabb társadalmi-gazdasági helyzetû́ vagy az elhízott egyének esetében jellemzően ennél hosszabb időtartam.

\section{Az egészséges öregedéshez kapcsolódó fogalmak}

Az egészséges öregedéssel kapcsolatos alapfogalmakról nincs egységes konszenzus, emiatt szükségesnek tartjuk a széles körben elfogadott definíciók áttekintését (a nemzetközi irodalomban használt kifejezésekkel).

- Egészség: az egészség az egyén élettani, mentális és társadalmi jóllétének betegségtôl és korlátozottságoktól mentes állapota.

- Élettartam (lifespan): az az időtartam, amelynek során az egyén túlél, életben van, illetve a fajra jellemző, adott életfeltételek mellett várható átlagos élethossz (1. ábra).

- Egészségtartam (healthspan): az az időszak, amelyet az egyén az egészség állapotában tölt, illetve azon életévek várható értéke, amelyeket az adott népesség bizonyos korú és nemú tagja egészségproblémából adódó, mindennapi tevékenységeiben korlátozottság nélkül eltölt (1. ábra).

- Hosszú egészséges élet (longevity): a hosszú életet élő egyénekre jellemző tulajdonság. Míg az élettartam a születés és a halál közötti átlagos időszakra utalva az 


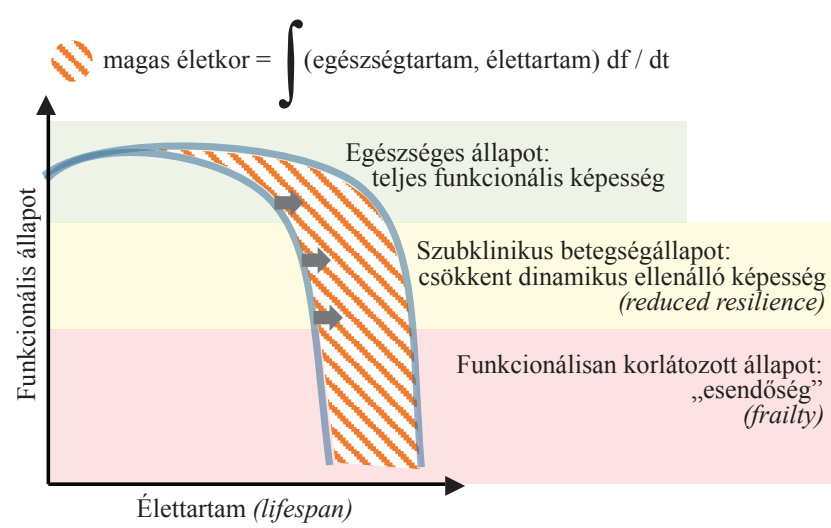

1. ábra

Az öregedéshez kapcsolódó fogalmak áttekintése. Az ember egészségtartamot az élettartam hosszmetszetében három fö szakaszra oszthatjuk: az egészséges állapotra, a szubklinikus betegségállapotra, valamint a funkcionálisan korlátozott állapotra

egyénre nézve prediktív értelmú, a hosszú élet sokkal inkább feltételes: az egyén azon képességét írja le, hogy hosszabb élettartamot érjen el ideális vagy az őt körülvevő körülmények között.

- Öregedés (ageing): az öregedés egyetemes biológiai jelenség, amely általában a nemi érettség elérését követôen a naptári kor emelkedésével (változó sebességgel) együtt járó funkcionális hanyatlás jellemző változásait összegzi. Az egyének eltérő ütemű öregedésével kapcsolatos megfigyelések vezettek a biológiai öregedés fogalmának bevezetéséhez. A biológiai öregedést a szervezet szintjén az élettani homeosztázis, azaz a mindennapi fizikai és kognitív feladatok elvégzéséhez szükséges képességek beszúkülése, sejtszinten pedig az őssejtek kimerülése, a senescens sejtek felszaporodása, megváltozott intercelluláris kommunikáció és mitochondrialis diszfunkció jellemzi. Molekuláris szinten az öregedésre jellemző biológiai sajátosságok a genomi instabilitás, a telomerek rövidülése, bizonyos epigenetikai változások, a fehérjék termelésében az alkalmazkodóképesség elvesztése és a tápanyag-érzékelés szabályozottságának kisiklása.

- Egészséges öregedés (bealthy ageing): a WHO az egészséges öregedést mindazon funkcionális képesség fejlesztésének és fenntartásának folyamataként határozza meg, amely idősebb korban is lehetővé teszi a testi-lelki jóllétet (wellbeing). A fogalom az alapvető szükségletek kielégítésén túl a tanulási képességre, fejlődésre, a döntéshozatalra, a mobilitási képességekre, kapcsolatok kialakítására, fenntartására és társadalmi szerepvállalásra is kiterjed. Nem jelent feltétlenül betegségektől vagy fogyatékosságoktól való mentességet, mivel sok idősödő egyénnek akár több olyan betegségállapota is lehet, amelynek az életminőségre csak kismértékü hatása van [3].

- Az egészség biomarkerei: azon jellemzők, amelyek a kronológiai életkornál pontosabban és részletesebben írják le az egészségtartam jövőbeli alakulását.
- „Az egészségtartam útvonalai” (healthspan pathways): az egészségtartamot befolyásoló erôs belső összefüggést mutató molekuláris hálózatok/modulok [3].

\section{A biológiai életkor becslése}

Az öregedés a funkcionális kapacitásnak és a külső streszszel szembeni ellenálló képességnek (resilience) a beszükülését jelenti az idő előrehaladtával, amelyet megnövekedett morbiditási és mortalitási kockázat jellemez. Gompertznek a 19. században tett megfigyelése szerint a 30 éves kor elérését követően a halálozási kockázat nagyjából 8 évente megduplázódik. Ezzel párhuzamosan bizonyos betegségek - mint a rák vagy a stroke - előfordulása hasonló trendet követ [4].

Az életkorhoz és az egyes betegségekhez hasonlóan az öregedés folyamata ugyanazon faj egyedei között - beleértve az embert is - jelentôs variabilitást mutat. Más szavakkal: az adott életkorban várható élettartam és egészségtartam igen személyfüggo", azaz a „biológiai életkor” eltérhet a születési dátum alapján adódó kronológiai kortól.

Az öregedés a szervezet legtöbb szövetét és szervét érintő folyamat. Az egyes élettani rendszerek múködészavara összekapcsolódik, több más szisztémára is kihathat, így például a metabolikus rendszerek múködési zavarai befolyásolhatják az immunrendszer állapotát is. $\mathrm{Az}$ öregedési folyamat általános tengelyeit, univerzális mechanizmusait - mint a DNS-károsodások felhalmozódása, a telomerhossz csökkenése, a mitochondrialis diszfunkció vagy a senescentia jelensége - a kutatások már molekuláris szinten tárják fel.

A naptár szerinti kornál többet árul el az egyénről a biológiai kora, amelyet azonban csak közelíteni lehet egyedi vagy kombinált, ún. helyettesítő (surrogate) végpontokkal, biomarkerekkel. Az Amerikai Öregedéskutatási Szövetség (American Federation for Aging Research) a következő kritériumokat javasolta az öregedés ideális biomarkereinek definiálására:

- Az öregedési folyamat előrehaladottságának pontos becslésére alkalmas.

- Az öregedés alapját képező életfolyamatot követi, nem pedig a betegségek következményeit.

- Többször is ismételhető legyen a vizsgálat, mint például egy vérvétel vagy képalkotó eljárás.

- Mind humán vonatkozásban, mind állatmodelleken alkalmazható legyen [3].

Az öregedési biomarkerek alapján több biológiai (élet) kori mutatóra is született javaslat, amelyek az egyes szervrendszerekre vagy szövetekre vonatkozhatnak.

Bizonyos élettani változók erós lineáris kapcsolata az öregedési folyamattal lehetővé teszi „biológiai órák”, azaz lineáris regressziós naptári kor - releváns élettaniparaméter-modellek megalkotását. Meglepően széles palettán találhatjuk ezen paramétereket az IgG glikozilációjától a vér vagy a liquor proteomján át egészen a bélmikrobióta összetételéig. Különösen figyelemre mél- 


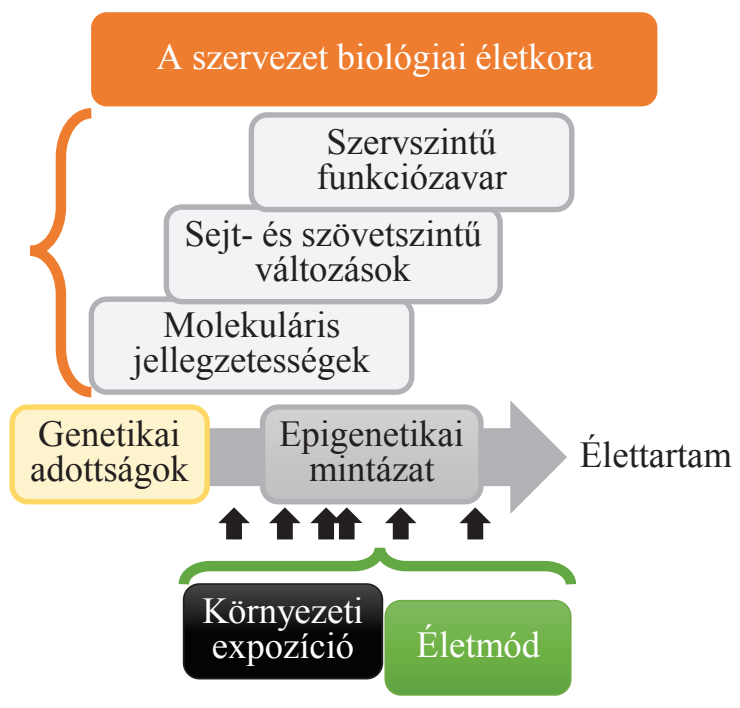

2. ábra A szervezet biológiai életkorának meghatározó tényezői. A
szervezet aktuális biológiai korát a kronológiai kor mellett az
örökítőanyagban kódolt genetikai adottságok, a környezeti ha-
tások szervezetre gyakorolt hatásai is módosítják, amelyek tartós
epigenetikai benyomatot hagyva is érvényre juthatnak

tó teljesítmény mérhető a genetikai információ feletti, környezeti tényezőket is leképező, epigenetikai szabályozási rétegben azonosított biomarkerek esetében (2. ábra). Az öregedés folyamatát kétségkívül markáns epigenetikai változások kísérik, amelyeket az idősödéssel az örökítőanyag kitüntetett pozíciókban történő metiláltsági mintázata jellemez. Számos emlősfaj elemzése azt mutatta, hogy a gének promotereiben a CpG-helyek sưrúsége - amelyek egyben a génexpresszió metilációfüggó szabályozásának jelentôs célpontjai - korrelál a fajra jellemző átlagos élettartammal. Az a megfigyelés, hogy a DNS metilációs mintázata előre jelezhetően változik az életkor előrehaladtával, lehetôvé tette a biológiai kort hatékonyan becslő, „óraszerú” biomarkerek kifejlesztését. Az öregedés előrehaladásának hátterében ezen életfolyamatoknak a szerepét tárták fel.

A „felgyorsult öregedés”, más néven a biológiai életkor akcelerációja úgy határozható meg, mint az egyénnek a biológiai életkorra vonatkozó becslése és a nem és életkor szerint illesztett kohorsz átlagos biológiai életkora alapján előre jelzett értéke közötti különbség. Ez a mutató emelkedett olyan krónikus betegségekben szenvedő egyéneknél, mint a HIV-fertőzés, a Down-szindróma vagy az elhízás. A biológiai életkor akcelerációja jól prognosztizálja az egészségtartamot is, így az utóbbi alkalmasnak tünik asszociált genetikai locusok eset-kontroll vizsgálatokban való azonosítására [5].

Az öregedési folyamat előrehaladásában mindenesetre több, a megújulóképesség beszúküléséhez vezető esemény is közrejátszik. Ezek között a legfontosabbak: (1) az össejtek kimerülése, (2) a megváltozott intercelluláris kommunikáció, (3) a genetikai instabilitás és (4) a telomerek rövidülése, (5) epigenetikai változások, (6) a fehérje-homeosztázis kisiklása, továbbá a (7) tápanyag- érzékelés szabályozatlanná válása, amelyeket (8) mitochondrialis diszfunkció és (9) sejtszintû́ senescentia is kísér $[6,7]$.

\section{Extrém humán fenotípusok az öregedés kutatásában}

A legismertebb, felgyorsult öregedéssel járó örökletes kórkép a Down-szindróma, amely a 21 . kromoszóma triszómiájának következtében alakul ki; a legfrissebb feltételezések szerint a 21 -es kromoszómán található USP16gén (ubiquitin carboxyl-terminal hydrolase 16) triszómiája miatt a gén által kódolt, a normálistól eltérő mennyiségben jelen lévő USPl6-enzim csökkenti a H2A-K119 ubiquitinatióját a regenerációra képes szövettípusokban, így az egységnyi sejtszintû stresszhatásra adott önmegújító válasz mértéke csökken, és a szomatikus őssejtek sejtszintű öregedési folyamatai felgyorsulnak [8].

A Down-szindróma mellett néhány igen ritka monogénes betegség is jól modellezi a felgyorsult öregedés élettani változásait. A Hutchinson-Gilford-féle progeriaszindróma (OMIM \#176670) hátterében a lamin A fehérjét kódoló $L M N A$-gén de novo mutációi állnak; megtartott kognitív fejlődés mellett alacsony testmagasság és testtömeg, korai kopaszodás, lipodystrophia, vékony, pergamenszerú bőr, csökkent ízületi mobilitás, csontritkulás és az idős emberekre jellegzetes arcvonások teszik felismerhetővé, rendszerint az első néhány életévben. A korai halált a szív- és érrendszeri betegségek okozzák [9].

A Werner-szindrómára - amelyet a WRN-helikáz gén biallélikus mutációi okoznak - akár egészen a pubertásig rejtve maradó, átfedő fenotípusú recesszív családfák jellemzőek. A pubertást követően a növekedés megáll, majd a 20-30-as életévekre nemcsak a felgyorsult öregedés jelei (a haj korai ôszülése, elvékonyodása, a bőr alatti zsír atrophiája) kísérik a betegséget, hanem számos, az öregedéssel általában összefüggő rendellenességgel is szövődik a kórkép. A szürke hályog, a cukorbetegség, a csontritkulás, a korai arteriosclerosis mellett jóindulatú és rosszindulatú daganatok szokatlan, a népességre általában jellemző prevalenciától eltérő eloszlási mintázata (például a pajzsmirigy, a bő́r daganatai, meningeoma, osteosarcoma) is megfigyelhető az érintettek körében [5].

Az öregedési folyamatban az örökítőanyag integritását megőrző mechanizmusok fontosságát két további progeriaszindróma is hangsúlyozza: a POLR3A-génhez köthető (és a lamin A-hoz hasonlóan a sejtmaghártya kialakulásában közremứködő) Wiedemann-Rautenstrauch-szindróma, illetve a $B A N F 1$-génnel asszociált, kifejezetten ritka, Néstor-Guillermo-féle progeriaszindróma. Az utóbbi különlegessége, hogy a többi progeriaszindrómától eltérően nem jellemző az érelmeszesedés, az ischaemia, illetve az anyagcsere-eltérések. 
A spektrum másik oldalán, ha nem is monogénes formában (mintegy „az örök élet génjének” bizonyítékául), de azért a lelassult öregedésre is találhatunk példát. A hosszú élettartam (longevity) tulajdonság meghatározható tetszőleges életkori, például 100 év feletti határértékek (centenarian) vagy akár egy adott, vizsgált populáció leghosszabb élettartamú, például 1\%-ába tartozók mentén is. Figyelemre méltó, hogy a „supercentenarian” egyének, akik a 110. életévüket is megérték, később tapasztalják meg az életkorral összefüggő betegségeket, miközben a betegségben töltött évek a teljes élettartam viszonylag rövidebb szakaszára terjednek ki. James Fries 1980-ban megfogalmazott elmélete szerint a halált megelőző, betegségben töltött életszakasz kezdetét, azaz az első krónikus, korlátozó betegségállapot fellépését lehet késleltetni (compression of morbidity). Néhány évvel ezelőtt egy ilyen, kivételesen magas életkort megélt személyeket vizsgáló kutatás során harminckét, 110 éven felüli személyt teszteltek. A vizsgálati adatok arra utalnak, hogy ezeknél az egyéneknél jelentősen később vagy egyáltalán nem alakultak ki cardiovascularis események. A személyek jelentős része a vizsgálatkor még mindig funkcionálisan önellátó volt, vagy csak minimális segítségre szorult [10].

Ez a hipotézis szemben áll azzal a prediktált fejleménynyel, hogy a fejlett társadalmakban az orvostudomány fejlődése meghosszabbítja a krónikus betegséggel és a fogyatékossággal élő személyek életét, de nem csökkenti ezeknek a betegségeknek az előfordulását, így a lakosság egészségben eltöltött életévei várhatóan csökkenni fognak (expansion of morbidity) [11]. Manton 1982-ben egy, a két véglet közötti „dinamikus egyensúly állapotát” feltételezte, amelynél a halálozás csökkenésével mérséklődik a test létfontosságú szervrendszereinek romlása is. Ez több betegséget okozhat a népességben, de a betegségek kevésbé lesznek súlyosak [12].

\section{Az öregedés multifaktoriális jellege}

A ritka, monogénes felgyorsult és poligénes meglassult öregedési ütemmel jellemezhető két szélsőség alkothatja egy képzeletbeli eloszlás széleit, amely között a normálpopuláció elterül. Hogyan használható ki a szélsőségeken alapuló ismeret a többség esetében? Az öregedés folyamata a korfüggő betegségek közös eleme, de számos degeneratív, krónikus betegségnek a fó rizikófaktora. A betegségekre való fogékonyság mértékében azonban lényeges egyéni variációkat lehet felfedezni. Az elmúlt évtizedek folyamán számos kutatásban bizonyították már az epigenetikai mechanizmusok fontos szerepét az öregedés folyamatában, valamint hogy a DNSmetiláció alapján múködő életkor-biomarkerek jó prediktorai lehetnek az életkorhoz kötött betegségek és a mortalitási rizikó becslésének [13].

Több európai ország ikerregisztereinek együttes elemzése alapján a hosszú élettartam varianciája mögött legfeljebb 25\%-ot tesz ki az örökletes háttér. Emberben az öregedési ütem meghatározottságának komplex multifaktoriális jellege mellett a viszonylag alacsonynak adódó heritabilitás hátterében egyéb tényezők is meghúzódnak. Miközben a hosszú életű egyének dúsulása bizonyos családokban régi megfigyelés, az élettartam heritabilitására vonatkozó becslések mégis következetesen alacsonynak ( 15-30\%) adódnak. Az Ancestry adatbázis aggregált, anonimizált, számos történelmi családfát felölelő adatszettjeinek vizsgálata alapján ráadásul úgy tünik, hogy még a 10\%-os örökletesség is túlzó, amely a nem random párválasztás (hasonló fenotípusú egyének kölcsönös párválasztási preferenciája: assortative mating) zavaró hatására vezethető vissza [14].

\section{Az egészséges öregedés nemzetközi kutatási programjai}

A sikeres öregedés (successful ageing) szempontjából fontos, hogy bizonyos protektív tényezők nem vizsgálhatók a modern humán társadalmak kontextusából kiragadva. A fejlett ipari országokban a testmozgás és az egészséges öregedés közötti összefüggés talán triviálisnak tünik, hatása azonban meglepő: egy, a heterogén definíciók harmonizálására törekvő metaanalízis szerint a magasabb fizikai aktivitás 39\%-kal növeli az egészséges öregedés esélyét [14].

Wellderly-kohorsz: Wellderly-fenotípusnak olyan, 80 év feletti egyéneket jellemeztek, akik nem szenvednek krónikus betegségben, és nem állnak rendszeres gyógyszeres kezelés alatt (1354 fóből álló kohorsz alapján nevezték el). Kizáró körülményt jelent a Wellderly-fenotípusból, ha valaki a következő krónikus betegségek valamelyikében szenved: autoimmun betegség, thrombemboliás kórképek, daganatos megbetegedés (kivételt jelent ez alól a basalioma és a bőr laphámsejtes carcinomája), diabetes mellitus, dementia, myocardialis infarctus, veseelégtelenség és bármely cerebrovascularis esemény előfordulása az egyén anamnézisében. Az eredeti amerikai kutatásba több mint 1300 személyt vontak be, akiknek életkora 80 és 105 év között mozgott. A férfiak és a nók életkori megoszlása hasonló görbét mutatott. A Wellderly-kohorszot alkotó vizsgálati személyek jellegzetességeit elemezve a következő konzekvenciákat vonták le: 1) minimális mértékben, de némileg magasabb volt a férfiak aránya; 2) a dohányos férfiak aránya is minimális mértékben emelkedett volt a korspecifikus kontrollpopuláció egyéneihez viszonyítva; 3 ) a vizsgálati személyek szignifikánsan több testmozgást, fizikai aktivitást végeztek az átlagnépességgel összehasonlítva, 4) az átlagnál vékonyabb testalkattal rendelkeztek, de ez a testsúly eloszlásának széles szórása miatt nem volt szignifikáns mértékü, 5) iskolai végzettségük az átlagnépességhez viszonyítva szignifikánsan magasabb szintű volt. (A felsorolt demográfiai jellemzőket az általános, egyesült államokbeli idős populációhoz viszonyították [15].)

Felmerülhet kritikaként, hogy egyszerüen csak egy sztochasztikus, életkorral összefüggő betegség-kockázat 
eloszlási görbe „jobb szélét” képezi le a kohorsz, amelyben a kritériumokat teljesítő egyének egyszerüen csak „szerencsések voltak”, és csupán a véletlennek tulajdoníthatóan kerülték el a mortalitással szövődő betegségeket. Ha ez így van, akkor feltételezhető, hogy a Wellderly-személyek testvérei sem élnek tovább, mint egy átlagos egyén, és hogy egyetlen közös, genetikai vagy környezeti tényezőnek sem kellene hatással lennie a testvérek túlélésére [15].

A Wellderly-tanulmány legfóbb megállapítása, hogy az egészséges öregedés genetikai háttere különbözik a kivételesen hosszú élettartamétól. Korábbi vizsgálatok összefüggést tártak fel a megnövekedett heterozigozitási arány (azaz a ritka és gyakori polimorfizmusok esetében a major és minor allél együttes jelenléte) és az alacsonyabb vérnyomás, össz/LDL koleszterin és halálozási kockázat között. Egy nem régi tanulmány eredményei alapján egyrészt az egészséges, magas életkort megélt egyének genomi heterozigozitása szignifikánsan magasabbnak bizonyult az általános populációéhoz képest, másrészt a magasabb heterozigóta-rátával rendelkező férfiak körében magasabb volt a 10 éves túlélési arány a hasonló korú férfiak túlélésével összehasonlítva [16].

A hosszú egészséges élet szempontjából a nagyobb arányú heterozigótaság előnye az lehet, hogy a nagy hatású, génexpressziós szabályozást érintő mutációk kialakulása esetén az optimálistól eltérő expressziós szintek kisebb mértékben alakulnak ki [16].

Seven Countries Study:1956-ban indítva úttörő jelentőségű kutatás volt, amely számos későbbi tanulmányt is ihletett ebben a témában. Megmutatta, hogy a szérumkoleszterinszint, a vérnyomás, a cukorbetegség és a dohányzás mind a coronariabetegség kialakulásának általános kockázati tényezói. A vizsgálatok során időskorú személyeket évtizedeken át követve kimutatták, hogy az egészséges táplálkozás és életmód (elegendő fizikai aktivitás, a dohányzás mellőzése és a mérsékelt vörösborfogyasztás) a szív- és érrendszeri betegségek alacsony kockázatával és csökkent mortalitással társul. Egyik fó következtetésként vonták le, hogy az egészséges táplálkozás és a megfelelő fizikai aktivitás késleltetheti a kognitív hanyatlást, és csökkentheti a depresszió kockázatát [17].

FINE Study (Finland, Italy, Netherlands Elderly Study): ez a vizsgálat a Seven Countries Study második szakasza, mely 1984-ben kezdődött. Ebben nemcsak a szívés érrendszeri kockázati tényezőkről gyújtöttek információkat, hanem az egészséges öregedés fizikai, mentális és társadalmi vonatkozásairól is. Az itt bevont idős férfiakat 25 éven át követték a halálozás szempontjából [18].

HALE Project (Healthy Ageing: a longitudinal study in Europe): ez a projekt 2001-ben indult, három addigi longitudinális tanulmány: a Seven Countries Study, a FINE Study és a SENECA projekt kiterjesztéseként. A HALE Project a Seven Countries Studyban összegyưjtött adatokat használta fel; öt európai országban (Finn- ország, Görögország, Olaszország, Hollandia, Szerbia) 7047, 40-59 éves férfit vontak be, akiket 35 éven át követtek [18].

Zutphen Elderly Study: 1960-ban a Hollandia keleti részén fekvő Zutphen városában élő 1088, 40-59 éves férfi közül 878-at véletlenszerüen vontak be ebbe a vizsgálatba, amely a Seven Countries Study hollandiai részének is tekinthető. A felmérés során EKG készült, valamint olyan fő cardiovascularis kockázati tényezőkrôl gyưjtöttek információkat, mint a szérum-koleszterinszint, a vérnyomás és a dohányzás. Ezt a felmérést az 1960 és 1973 közötti időszakban évente megismételték, valamint 1965-ban ezeket kiegészítették az energiafelhasználás és a légzésfunkció mérésével, 1970-ben pedig egy teljes glükóztolerancia-teszttel [19].

\section{A Magyar Genomikai Egészségtárház}

A Nemzeti Bionika Program keretei között 2018 júniusában indult a kutatásunk, amelynek során - hazánkban az első ilyen kezdeményezésként - 100 magyar egészséges, 75 év feletti személy teljesgenom-szekvenálását tűztük ki célul. A keletkező adattárházban a genomialis szekvenciaadatok mellett a kapcsolódó fenotípusadatok is megjelentek ezáltal, teljes genomialis referencia-adatbázist alkotva. Fontos szempont volt, hogy a kutatás kapcsolódást biztosítson az egészséges öregedést kutató nemzetközi projektekhez is, például a Wellderly-fenotípus magyarra adaptálásával lehetőséget teremtve az adatok harmonizálására és közös elemzésére.

A Magyar Genomikai Egészségtárház létrehozásához kapcsolódó bioinformatikai fejlesztések célja, hogy többszintü hozzáférést biztosítson a genetikai adatok hazai gyakorlati alkalmazásához. A kohorsz újgenerációs szekvenálással generált adatai egy új magyar referenciát, az első hazai nyilvános teljes genomi adatbázist jelentik a hazai genetikai kutatások és a molekuláris diagnosztika számára, amely a gyakori polimorfizmusokon túl a hazai populációspecifikus ritka variánsokat, illetve akár egyéni mutációkat is tartalmaz. Nemzetközi mintákat követve $[13,20]$, a Magyar Genomikai Egészségtárház adatainak elérhetőségét a kutatói közösség számára több szinten tervezzük megvalósítani: (1) a Global Alliance for Genomics and Health által kifejlesztett szabvány, a Beaconprotokoll implementációja egyedi genomi pozíciókban fellelhető variánsok előfordulásának vagy éppen hiányának a lekérdezhetőségét teszi lehetővé; (2) a kohorsz (és a későbbiekben akár a munkacsoport további genomi adattárainak) anonim aggregált statisztikai adatai manuális és automatizált lekérdezéssel is elérhetők lesznek; (3) megfelelő jogosítványokkal rendelkező intézmények, kutatási együttmúködők számára az adatok személyes jellegének védettségét megőrző eljárásokon keresztül az egyéni szintű adatok statisztikai és gépi tanulási elemzései is elérhetők lesznek. Míg az első két lépcsőben az adatvédelmi kérdések kezelése nem szükséges, illetve könnyen feloldható, addig a harmadik esetben az egyéni 
szintű mérési tömböknek egy adott személyhez kapcsolása pusztán a személyazonossági adatokat elválasztó anonimizálással nem lehetséges. A DNS variációinak egyedi kombinációja ugyanúgy személyes, védelemre kiemelten érdemes adatnak számít, mint a születési dátum vagy a társadalombiztosítási azonosító jel. A problémára az elmúlt évtizedben kifejlesztett, gépi tanuláson alapuló technika kínál megoldást, amely a személyes adatok titkosságát genetikai szinten is megörzi (privacy-preserving genomic data sharing).

A Magyar Genomikai Egészségtárház beválasztási kritériumainak felállítása során az eredeti Wellderly-kohorsz paramétereit képeztük le. Ez alapján aktív, jó általános állapotú, 75 év feletti magyar állampolgárok bevonása volt a célunk. A legfontosabb kizárási kritérium az életminőséget korlátozó, rendszeres kontrollt igénylő krónikus betegség jelenléte (diabetes mellitus, szívelégtelenség, ischaemiás szívbetegség, korábbi agyi vascularis esemény, daganatos betegség, neurodegeneratív betegség, dementia) volt. Ebből értelemszerúen adódott, hogy nem választhattuk be a csoportba azokat az egyéneket, akik olyan gyógyszereket szedtek, amelyek a fent felsorolt betegségcsoport jelenlétére utaltak (antikoaguláns szerek, antidiabetikumok, Alzheimer-kórban használatos kolinészteráz-inhibitorok).

A vizsgálatba történő bevonás első lépcsőjeként kérdöívet töltöttek ki a vizsgálati alanyok, amelynek során a következő témakörökre kérdeztünk rá: geográfiaiszocioökonómiai paraméterek, családi anamnézis (külö-

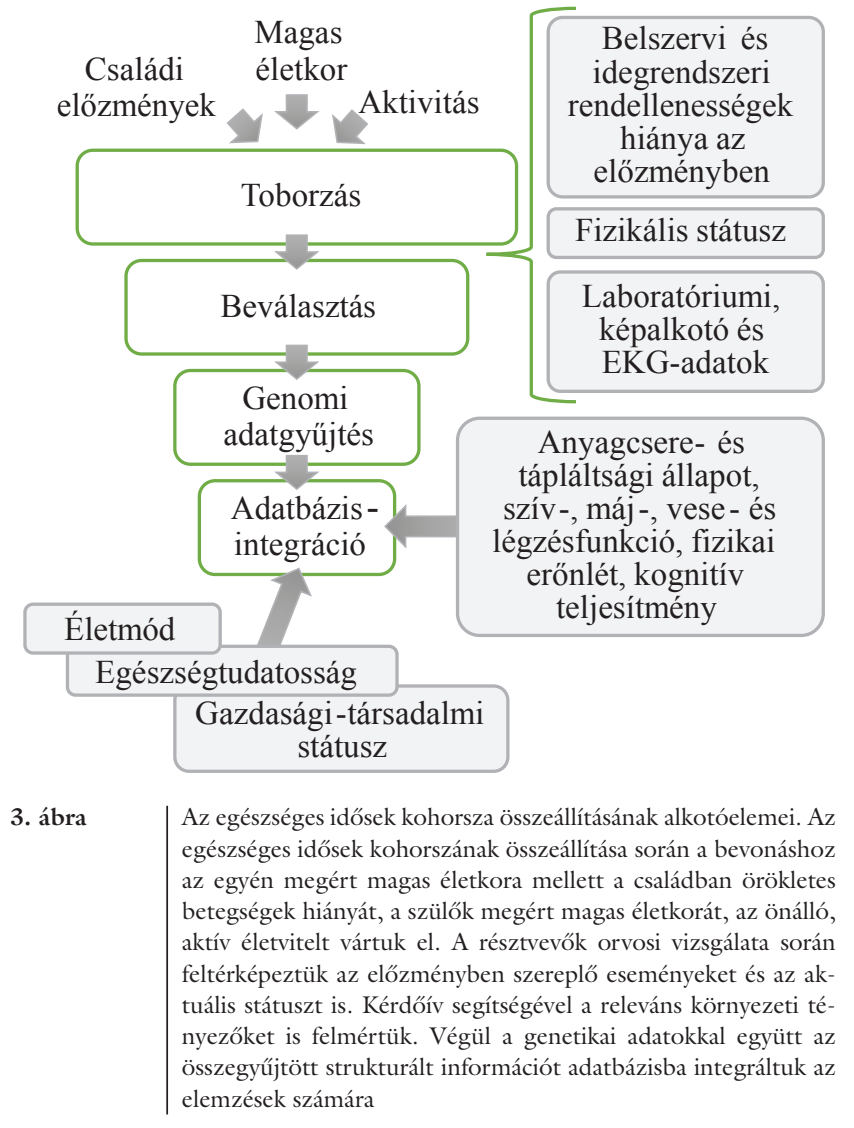

nös tekintettel a szülők, nagyszülők élettartamára és származására), a fontosabb krónikus betegségcsoportok megléte/hiánya, a rendszeresen szedett gyógyszerek és vitaminok, táplálékkiegészítők listája, esetleges mútéti beavatkozások, a mindennapi életmód jellegzetességeinek leírói (a jelenleg, illetve fiatalabb korban végzett rendszeres sport/testmozgás típusa, jellege), káros szenvedélyek jelenléte/hiánya (3. ábra).

A vizsgálati személyek toborzása többféle kommunikációs csatornán (közösségi portálok, hírportálok, televíziós riportok, idősklubokban ismeretterjesztő előadások stb.) keresztül egyidejúleg az ország számos pontján történt. Ennek ellenére megállapítható bizonyos közös statisztikai jellemző a földrajzi és a szociológiai eloszlás sajátosságait illetően, ugyanis túlnyomó többségben a fơvárosban élő, magasabban kvalifikált, előnyösebb társadalmi státusszal rendelkező egyének alkották a jelentkezők nagyobb hányadát, akik egészségtudatosabb életmódot folytattak már egészen fiatal koruktól kezdve. Ugyanakkor nem elhanyagolható szempont, hogy a kohorszunkat alkotó személyek jelentős százalékánál a szülők is magasabb életkort éltek meg, azonban a két világháború torzító hatással bírt ennek a paraméternek az objektív értékelése során.

Az adatgyüjtést követően valamennyi önkéntes jelentkező fizikális belgyógyászati és neurológiai vizsgálata megtörtént, a rutin laboratóriumi adatokat, a mellkasröntgen, az EKG eredményeit értékeltük, és a kognitív funkciók értékelésére a MoCA-tesztet (Montreal Cognitive Assessment) végeztük el. A MoCA-tesztben a 28/30 pontszám alatt teljesítőket kizártuk a kohorszból.

A felvett demográfiai, életmóddal kapcsolatos, valamint egészségügyi adatok egy strukturált adatbázisban kerültek tárolásra. A teljesgenom-szekvencia adatai független, nagy tárhelykapacitású szerveren kerültek elhelyezésre.

A kutatásban részt vevő személyek 49\%-a 70-80 éves, 36\%-a 81-90 éves, 14\%-uk pedig 90 év feletti, a nemek aránya 44/56\%-os megoszlást mutatott a férfiak és a nők között. A résztvevők csaknem fele (46\%) egyedül él, ezt követi gyakoriságban az otthonukat a házastársukkal megosztók csoportja (40\%), 7\%-uk pedig gyermekével vagy testvérével él közös háztartásban. Magas a felsőfokú végzettségüek aránya (46\%), amiben - az alacsony mintaszám és a mintavételezési torzítás mellett - az iskolázottság és az élettartam közötti ismert egyenes arányosság is szerepet játszhat. A hosszú élettartam elérésében az iskolázottság mellett egy másik ismert, részben független tényező a társadalmi-gazdasági helyzet. Összességében átlagos jövedelmúnek vallották magukat (átlag \pm CI 95\%: 5,69 \pm 0,39; a 0: nagyon rossz és a 10: nagyon jó közötti skálán elhelyezve a család anyagi helyzetét), ugyanakkor 6\%-uk számára az alapvető árucikkek beszerzése is nehézséget okoz. A 20. század derekán már jócskán érzékelhető demográfiai trendeknek megfelelően csak 16\%-uk vállalt 3 vagy több gyermeket, jóllehet 59\%uk még olyan családban nőtt fel, amelyben legalább 3 


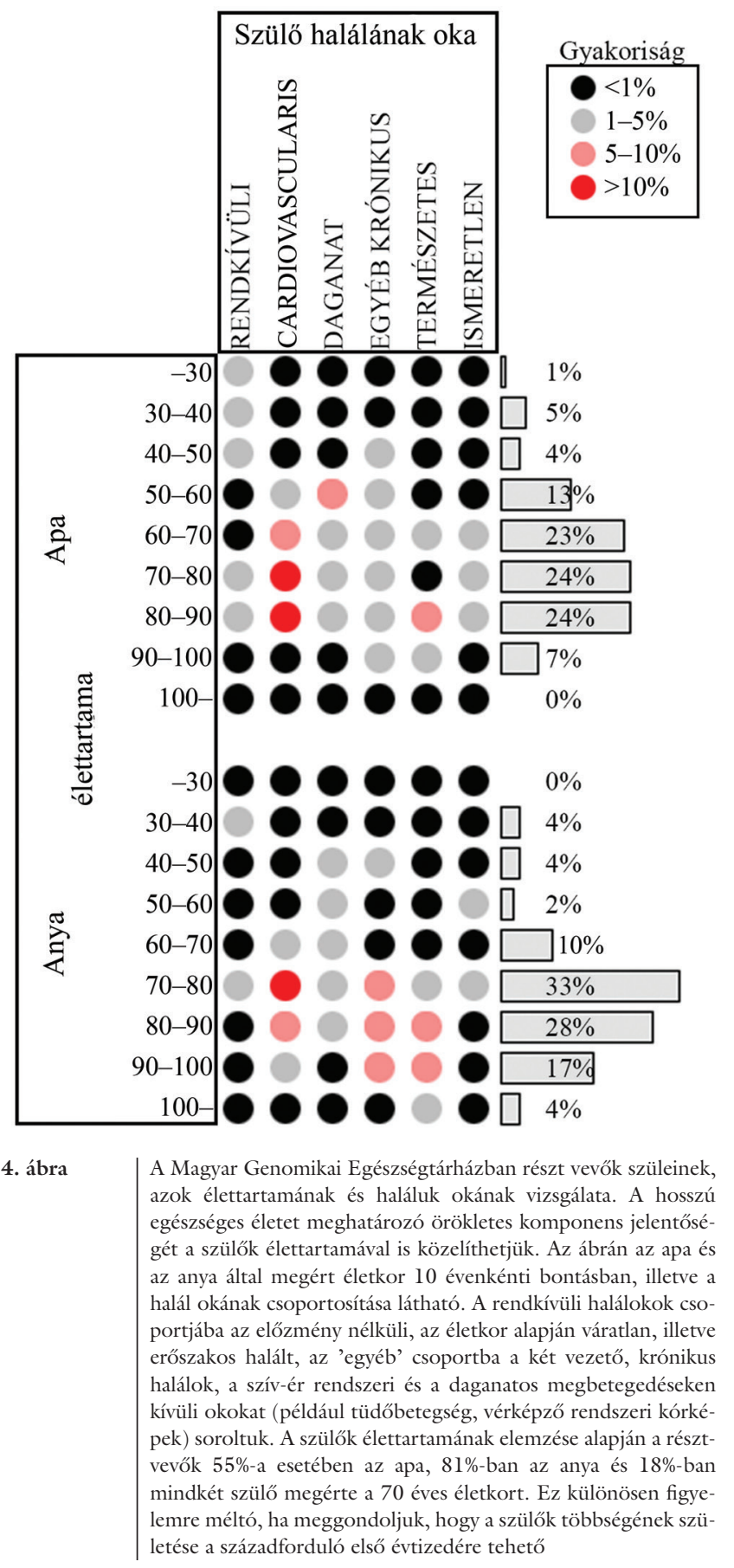

gyermek született. Lakóhelyüket tekintve a vizsgálati alanyok 56\%-a fóvárosi, 12\%-uk valamelyik megyeszékhelyen él, 27\%-uk kisvárosi, míg községben a részt vevő személyeknek mindösszesen az 5\%-a él. Az egészségtudatosság tekintetében figyelemre méltó, hogy a résztvevők $61 \%$-a hosszú időn át sportolt élete során, ső́t 25\%uk (!) még most is folytat naponta valamilyen testmozgást. Igaz, 32\%-uk soha életében nem sportolt rendszeresen. Saját kortársaikkal összevetve jobbnak (56\%) vagy sokkal jobbnak $(27 \%)$ látják saját egészségi állapotukat. Nem meglepő a befolyásolható rizikófaktorok hiánya, 70\%-uk sosem dohányzott, az erős dohányosok aránya (legalább
20 csomag/év) mindössze 3\%-ra tehető. A vizsgálati alanyok szüleinek elhalálozási okát nemek szerinti bontásban a 4. ábrán szemléltetjük. A vizsgálati alanyok szüleinek élettartama átlagosan az édesapák esetében 74,3 év, az édesanyák esetében pedig 80,47 év, mindkét szülőnél összesítve 72,39 év (a kalkuláció során nem számítottuk be a korai baleset vagy háborús körülmény okozta halálozásokat, csak a krónikus betegség, illetve a természetes öregedés során elhunytak életkorával számoltunk).

\section{Az egészséges élet titkát kereső kutatások társadalmi haszna}

A jelen projektben fejlesztett Egészségtárházban tárolt genomi adatok a kutatók számára fontos infrastruktúrát biztosítanak egyrészt azzal, hogy a hazai populáció specifikus variánsainak azonosítását teszik lehetôvé, így azok jól elkülöníthetővé válnak a betegséggel, gyógyszerhatással asszociált variánsoktól, különösen a ritka betegségek hazai vizsgálata esetén. Másrészt információt kapnak a szakirodalomban közölt, az egészséges élettartammal összefüggést mutató variánsok hazai vonatkozásairól, amelyek támogatják az egészséges élet minél hosszabb ideig való megtartását célzó projekteket [20-22].

A hazai egészségügyi ellátásban egyre gyakrabban előforduló helyzet, hogy bizonyos genetikai variánsok szerepét a hazai populációgenetikai sajátosságok ismeretének hiányában nem lehet megítélni. A ma élő magyarok genomját nem ismerjük olyan mélységben, hogy biztonsággal tudjuk megbecsülni az egyes betegségekre való hajlamokat, a gyógyszerek hatékonyságát/mellékhatását, pedig a személyes egészségmegőrzési stratégiák felállításában alapvető fontosságú minden nemzetben az egészséges genom ritka variánsainak ismerete. A rendelkezésre álló populációs genomi adattárházak azon túl, hogy más populációs sajátosságokat tartalmaznak, általában nem szürtek betegségekre („unscreened control”), különösen nem időskori megbetegedésekre. A populációgenetikai sajátosságok mellett így az egészségkutatás modern genetikai megközelítései is relevánsak egy általános kontroll („referencia”) genetikai adatbázis megtervezésében, mivel egyre részletesebben tárják fel az egyes betegségek rizikófaktorai mellett az egészséges öregedés általános védőfaktorait. Továbbá az egy népcsoportra jellegzetes ritka DNS-variációk megismerése és elemzése kiszolgálja az orvosbiológiai, populációgenetikai és antropológiai kutatásokat is.

\section{Következtetés}

A genom variációi fontos alappillérét képezik a jövő orvoslásának, a precíziós orvoslásnak. Az egyes populációk genomi variációinak ismerete nemcsak a kutatásokban, hanem az egészségügyi ellátásban és az egészségmegőrzési stratégiák kialakításában is fontosak. A modern orvostudomány egyre inkább a genomikai markerek alapján igyekszik a betegségeket prediktálni, stratifikálni, az 
optimális kezelési módot kiválasztani. Minden populációnak megvannak a jellegzetes ritka variánsai, így ezek ismerete nagymértékben segíti az egyes betegségekkel aszszociált ritka genetikai variánsok azonosítását a fenti célok érdekében. Egy, a magyarhoz hasonló kis-közepes méretû́ népességben különösen fontos a genetikai variációk populációspecifikus jellegzetességeinek megismerése, mivel a nemzetközi genomikai adatbázisok csak részben képesek kielégíteni a személyre szabott gyógyításhoz kapcsolódó genetikai tesztek értékelése során felmerülő igényeket.

Az öregedés az élet elkerülhetetlen következménye. $\mathrm{Az}$ egészségügy napjainkban zajló reformjának egyik fó mozgatórugója a precíziós orvoslás implementációja a klinikai gyakorlatba. Ennek egyik feltétele az egyes betegségek kialakulására hajlamosító ritka és gyakori variánsok ismerete mellett az egészséges hosszú élettel aszszociált, adott populációra jellegzetes variánsok ismerete. Ezt célozza meg a Magyar Genomikai Egészségtárház, amelyben 75 év feletti, egészséges egyének teljesgenomszekvenciái és a hozzá kapcsolódó fenotípusadatai gyúlnek. Az így létrehozott kutatási infrastruktúra orvosbiológiai, populációgenetikai és antropológiai kutatások alappillérét képezi.

Fontos kiemelni a Magyar Genomikai Egészségtárház által biztosítani kívánt hazai teljes genomi adatbázis közvetlen gyógyászati jelentőségét: a szekvenciaadatok felhasználásának a klinikai gyakorlatban történő széles körü elterjedésével a ritka betegségek diagnosztikájában megkerülhetetlenül szükséges egy variáns előfordulási gyakorisága a kóroki jelentőségének megítéléséhez. A modern, személyre szabott gyógyászatban egy variáns adott fenotípussal való együttes megjelenése olyan kritikus információt jelent, amely jó minőségű, adott népességre vonatkozó adatokkal kiegészített populációs adatsilók nélkül egyszerűen pótolhatatlan.

Adattárházunk elsóként tervez személyes genetikai adatok védettségét megőrző, többszintü hozzáférést biztosítani egy hazai, magyar teljes genomi referenciaadatbázishoz, amely a genetikusan meghatározott betegségek és fenotípusok kutatásában és a klinikai gyakorlatban is alapvető fontosságú. Az első 100 egészséges idős magyar genommal indított Adattárházunk egy dinamikusan bővíthető kutatási infrastruktúra alapját célozta létrehozni. A jövőben az architektúrát, a kifejlesztett eszköztárat is magában foglaló megoldás a kiindulási elemszámnál lényegesen több adatot is képes befogadni, amennyiben az ezt követő projektek felépítése a harmonizációt lehetővé teszi. Egészségtárházunkat a jelenleg megvalósítás alatt álló európai uniós kezdeményezés, az 1 Millió Genom Projekt [23] és a most megalakuló BBMRI (Biobanking and BioMolecular Resources Research Infrastructure) magyar csomópont biobankja fontos építőköveinek egyaránt szánjuk [24].
Anyagi támogatás: A Magyar Genomikai Egészségtárház projekt megvalósítását a Nemzeti Bionika Program ED_17-1-2017-0009. és az OTKA 119866. számú pályázata támogatta.

Szerzői munkamegosztás: V. V.: A vizsgálat lefolytatása. M. V.: A vizsgálat struktúrájának tervezése. M. M. J., A. P.: A hipotézisek kidolgozása, a munka koordinálása. G. A., S. P., A. P.: A bioinformatikai feladatok megoldása, statisztikai elemzések. V. V., M. V., M. M. J.: A kézirat megszövegezése. V. V., M. V., G. A., S. P., A. P., M. M. J.: A kézirat véleményezése. A cikk végleges változatát valamennyi szerző elolvasta és jóváhagyta.

Érdekeltségek: A szerzőknek nincsenek érdekeltségeik.

\section{Köszönetnyilvánítás}

A szerzők köszönetüket fejezik ki minden egyénnek, aki a Nemzeti Egészségtárház programot önkéntes részvételével támogatta. A Genomikai Medicina és Ritka Betegségek Intézete az Európai Referencia Hálózatok (ERN) Ritka Neurológiai Betegségek és Neuromuscularis Betegségek Hálózatának a tagja.

\section{Irodalom}

[1] Cucinotta D. Preparing for the Decade of Heathy Aging (20202030): prevention plus therapy? Acta Biomed. 2018; 89: 145147.

[2] World Health Organization, National Institute on Aging, National Institutes of Health. Global Health and Aging. NIH Publication no. 11-7737, 2011; pp. 1-32.

[3] Fuellen G, Jansen L, Cohen AA, et al. Health and aging: unifying concepts, scores, biomarkers and pathways. Aging Dis. 2019; 10: 883-900.

[4] Christensen K, Doblhammer G, Rau R, et al. Ageing populations: the challenges ahead. Lancet 2009; 374: 1196-1208.

[5] Dreesen O, Stewart CL. Accelerated aging syndromes, are they relevant to normal human aging? Aging (Albany NY) 2011; 3 : 889-895.

[6] Khan SS, Singer BD, Vaughan DE. Molecular and physiological manifestations and measurement of aging in humans. Aging Cell 2017; 16: 624-633.

[7] Wagner KH, Cameron-Smith D, Wessner B, et al. Biomarkers of aging: from function to molecular biology. Nutrients 2016; 8 : 338.

[8] Souroullas GP, Sharpless NE. Stem cells: Down's syndrome link to ageing. Nature 2013; 501: 325-326.

[9] Gonzalo S, Kreienkamp R, Askjaer P. Hutchinson-Gilford progeria syndrome: a premature aging disease caused by $L M N A$ gene mutations. Ageing Res Rev. 2017; 33: 18-29.

[10] Schoenhofen EA, Wyszynski DF, Andersen S, et al. Characteristics of 32 supercentenarians. J Am Geriatr Soc. 2006; 54: 12371240 .

[11] Kingston A, Robinson L, Booth H, et al. MODEM project. Projections of multi-morbidity in the older population in England to 2035: estimates from the Population Ageing and Care Simulation (PACSim) model. Age Ageing 2018; 47: 374-380.

[12] Rizzuto D. Living longer than expected: protective and risk factors related to human longevity. Doctoral thesis. Department of Neurobiology, Care Science and Society, Karolinska Institutet, Stockholm, 2013. 
[13] Johnson TE. Recent results: biomarkers of aging. Exp Gerontol. 2006; 41: 1243-1246.

[14] Ruby JG, Wright KM, Rand KA, et al. Estimates of the heritability of human longevity are substantially inflated due to assortative mating. Genetics 2018; 210: 1109-1124.

[15] Erikson GA, Bodian DL, Rueda M, et al. Whole-genome sequencing of a healthy aging cohort. Cell 2016; 165: 1002-1011.

[16] Xu K, Kosoy R, Shameer K, et al. Genome-wide analysis indicates association between heterozygote advantage and healthy aging in humans. BMC Genet. 2019; 20: 52.

[17] Keys A, Menotti A, Aravanis C, et al. The seven countries study: 2,289 deaths in 15 years. Prev Med. 1984; 13: 141-154.

[18] Knoops KT, de Groot LC, Kromhout D, et al. Mediterranean diet, lifestyle factors, and 10-year mortality in elderly European men and women: the HALE Project. JAMA 2004; 292: 14331439.

[19] Hertog MG, Feskens EJ, Hollman PC, et al. Dietary flavonoids and cancer risk in the Zutphen Elderly Study. Nutr Cancer 1994; 22: 175-184.

[20] Pinese M, Lacaze P, Rath EM, et al. The Medical Genome Reference Bank contains whole genome and phenotype data of 2570 healthy elderly. Nat Commun. 2020; 11: 435.
[21] Zenin A, Tsepilov Y, Sharapov S, et al. Identification of 12 genetic loci associated with human healthspan. Commun Biol. 2019; $2: 41$.

[22] Timmers PR, Mounier N, Lall K, et al. Genomics of 1 million parent lifespans implicates novel pathways and common diseases and distinguishes survival chances. eLife 2019; 8: e39856.

[23] Saunders G, Baudis M, Becker R, et al. Leveraging European infrastructures to access 1 million human genomes by 2022 . Nat Rev Genet. 2019; 20: 693-701. [Erratum: Nat Rev Genet. 2019 Sep 13.] PMID: 31455890; PMCID: PMC7115898.

[24] van Ommen GJ, Törnwall O, Bréchot C, et al. BBMRI-ERIC as a resource for pharmaceutical and life science industries: the development of biobank-based Expert Centres. Eur J Hum Genet. $2015 ; 23: 893-900$

(Molnár Mária Judit dr., Budapest, Üllői út 26., 1085 e-mail: molnar.mariajudit@med.semmelweis-univ.hu)

\section{"Gaudeamus igitur, iuvenes dum sumus." (Addig örüljünk, míg fiatalok vagyunk.)}

A cikk a Creative Commons Attribution 4.0 International License (https://creativecommons.org/licenses/by/4.0/) feltételei szerint publikált Open Access közlemény, melynek szellemében a cikk bármilyen médiumban szabadon felhasználható, megosztható és újraközölhető, feltéve, hogy az eredeti szerzỏ és a közlés helye, illetve a CC License linkje és az esetlegesen végrehajtott módosítások feltüntetésre kerülnek. (SID_1) 